Н. П. Медведев, Г. Л. Билич. Нарушения гомеостаза у хирургических больных и возможности их коррекции. Казань, изд-во Казанского ун-та, 1982, 272 с.

Книга посвящена изучению гомеостаза у хирургических больных при некоторых нанболее распространенных заболеваниях (гнойной хирургической инфекции, остром аппендиците, остром холецистите, остром панкреатите, острой кишечной непроходимости, язвенной болезни желудка и двенадцатиперстной кишки, остром перитоните, нагноительных заболеваниях легких и плевры, ожоговой болезни). Монография основана на многолетних собственных наблюдениях авторов и руководимых ими крупных коллективов, в ней критически анализируются и данные современной литературы. Особую ценность книге придает сочетание вопросов клинического подхода с глубокими теоретическими исследованиями, широкое использование результатов достижений теоретических наук и фармакологии в повседневной хирургической практике.

Монография состоит из 9 глав. Основное внимание уделено двум важным разделам хирургии - острому животу и гнойной хирургической инфекции. В каждой из глав органически взаимосвязаны собственные и литературные данные, которые разносторонне освещают обменные нарушения, связанные с заболеваниями, оперативным вмешательством и, что чрезвычайно важно, предлагаются методы коррекции возникших расстройств. Краткие сведения об этиологии, патогенезе заболеваний, классификации и схемы значительно облегчают чтение и могут оказать неоценимую помощь практическому врачу. На мой взгляд, совершенно оправдан параллельный анализ обменных нарушений у взрослых и детей, что позволяет выявить ряд важных обших закономерностей, единых методических подходов и в то же время показать особенности изменений гомеостаза у больных различных возрастных групп. Авторы правильно обращают внимание на сходство процессов у детей и взрослых, зависящих от характера патологии.

Через всю книгу красной нитью проходит мысль о ведушей роли макроорганизма, его сопротивляемости, защитных механизмов в возникновении и течении патологического процесса и о необходимости воздействия в первую очередь на защитные реакции макроорганизма. Многолетний собственный опыт позволяет мне приветствовать такой подход в изложении материала. Считаю необходимым особо остановиться на рекомендации пиримидинов для широкого применения в хирургии. Авторы приводят теоретические обоснования к использованию в хирургии пентоксила, метилурацила, оротата калия и на многочисленных клинических примерах подробно анализируют влияние препаратов на обмен вешеств в организме.

Большое практическое значение имеет разработка комплекса информативных и доступных тестов, которые позволяют решать вопросы диагноза, прогноза и эффективности проводимой терапин.

Авторы неоднократно и настойчнво рекомендуют широкое изучение у хирургических больных ферментного статуса циркулирующих лейкощитов как одного из наиболее информативных тестов. Следует полностью согласиться с ними и высказать сожаление, что эти методы исследования медленно внедряются в практику хирургов.

Будучи хорошо знакомым с предыдушими публикациями Н. П. Медведева и Г. Л. Билича, считаю необходимым подчеркнуть, что данная монография является как бы их продолжением, написана оригинально, с более широких и перспективных позиций.

Вместе с тем считаю необходимым указать на ряд недостатков. В первую очередь это касается отсутствия полного указателя литературы. Монография перегружена изложением экспериментальных и лабораторных данных, а также таблицами, часть которых плохо воспринимается из-за обилия цифр. В предпосылке к схеме № 1 (c. 5) надо было сослаться на аналогичные схемы, опубликованные в литературе (в частности в моих книгах, указанных в библиографии), и рассматривать эту схему как более совершенную по сравнению с известными. В книге мало графиков и рисунков, некоторые положения надо было проиллюстрировать микрофотографиями. Не все клинические примеры (выписки из историй болезней) демонстративны, а некоторые велики. Однако все указанные недостатки не являются принципиальными.

Вызывает удивление, что такая интересная и нужная книга издана незначительным тиражом.

Проф. В. И. Русаков (Ростов-на-Дону).

\title{
ЮБИЛЕИНЫЕ ДАТЫ
}

УдК 616-091 (092 Добрынин)

\section{ПРОФЕССОР ВИТАЛИЙ АЛЕКСЕЕВИЧ ДОБРЫНИН}

В январе 1983 г. исполнилось 60 лет со дня рождения Виталия Алексеевича Добрынина, заведующего кафедрой патологической анатомии Қазанского медицинского института им. С. В. Курашова. 
В. А. Добрынин родился 5 января 1923 г. в г. Парфеньеве Костромской области в семье служащего. С 1943 г. по окончании Киевского военно-медицинского училища B. А. Добрынин участвовал в Великой Отечественной войне в качестве фельдшера батальона 1-го Белорусского фронта. За боевые заслуги он был награжден медалями.

После демобилизации из рядов Советской Армии в 1947 г. Виталий Алексеевич Добрынин поступил в Ивановский медицинский институт, который закончил с отличием в 1952 г. Окончив аспирантуру при кафедре патологической анатомии того же института, в 1955 г. успешно защитил кандидатскую диссертащию на тему «Патологическая анатомия и некоторые вопросы патогенеза геморрагических инфарктов легких», посвященную различным факторам, определяющим механизмы и особенности течения этого довольно частого и подчас смертельного осложнения сердечно-сосудистой недостаточности. До 1960 г. работал ассистентом на кафедре патологической анатомии Ивановского медицинского института. В 1960 г. был избран на должность доцента кафедры патологической анатомии Кемеровского медицинского института, а с сентября 1962 г, стал заведовать этой кафедрой, исполняя одновременно обязанности декана лечебного факультета института. В сентябре 1963 г. избирается доцентом кафедры патологической анатомии Кубанского мединститута, а с апреля 1969 г. возглавляет кафедру патологической анатомии Казанского медицинского института.

B. А. Добрынин является высококвалифицированным патологоанатомом, владеющим всеми современными гистологическими и гистохимическими методами исследований. Его докторская диссертация «Некоторые вопросы гистогенеза и патогенеза бронхогенного рака легких», защищенная в 1968 г., представляет собой солидный труд, посвяненный одному из сложнейших разделов патологии. В диссертации подробно освешены взаимосвязь и взаимозависимость между инволютивными, воспалительными

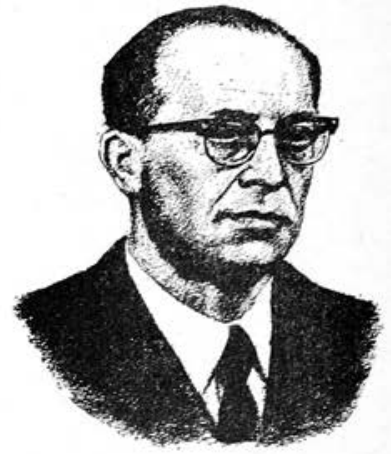
процессами и раком легких; раскрыты взаимодействия между процессами регенерации, метаплазии бронхиального эпителия и раком бронхов и определены факторы риска, что является чрезвычайно важным при разработке профилактических мероприятий. Под редакцией В. А. Добрынина изданы сборники научных трудов «Bопросы морфологии и клиники злокачественных опухолей» (Краснодар, 1967) и «Морфология сосудистой системы в норме и патологии» (Казань, 1977). Им выполнено и опубликовано более 80 научных работ, в которых нашли отражение вопросы онкологии и патологии легких, он соавтор монографии «Рак легкого» (М., Медицина, 1971). Под руководством В. А. Добрынина защищено 4 докторских и 10 кандидатских диссертаций.

B. А. Добрынин - талантливый педагог и лектор, пользуюшийся заслуженным уваженнем и любовью студентов. Лекции его глубоко содержательны, логичны, доходчивы, прекрасно иллюстрированы. Большое внимание он уделяет реорганизации учебного процесса, совершенствованию и улучшению наглядности в преподавании патологической анатомии. При его непосредственном участии созданы наборы высококачественных слайдов, насчитывающие около 1000 наименований. Серьезная работа проведена им по оборудованию кафедры, реставрацин ценнейшего и богатейшего музея кафедры, который широко известен среди врачей и студентов.

Учебно-методическую и научную работу профессор В. А. Добрынин умело сочетает с многогранной общественной деятельностью. Он входит в состав парткома института, является руководителем философского семинара, членом проблемной и председателем предметно-проблемной комиссии института, членом методической комиссии. лечебного факультета института, председателем Казанского и членом правления Всесоюзного научных обществ патологоанатомов. Как член комиссни по родовспоможению и как главный внештатный патологоанатом Минздрава ТАССР В. А. Добрынин активно участвует в совместной работе с органами практического здравоохранення, занимается реорганизацией и совершенствованием патологической службы. Свой богатый практический опыт патологоанатома он щедро передает врачам и своим ученикам; его консультации по аутопсиям и биопсиям являются хорошей школой для врачей патологоанатомов, патогистологов.

Эрудиция, высокое педагогическое мастерство, принципиальность, требовательность и внимательное отношение к товаришам, чуткость снискали профессору В. А. Добрынину глубокое уважение, заслуженный авторитет и признательность коллег, учеников и студентов.

За плодотворную работу профессор В. А. Добрынин награжден орденом «Знак почета».

Сотрудники кафедры патологической анатомии, коллеги, ученики и редколлегия «Казанского медицинского журнала» сердечно поздравляют Виталия Алексеевича Добрынина со славным юбилеем, желают ему здоровья, счастья, долгих лет плодотворной деятельности.

Сотрудники, ученики. 